\section{Leaf Nutrient Levels for Pecans}

Andrew P. Pond and James L. Walworth ${ }^{\mathbf{1}}$

Department of Soil, Water and Environmental Science, University of Arizona, 429 Shantz Bldg. \#38, Tucson, AZ 85721

Michael W. Kilby

Department of Plant Science, University of Arizona, 303 Forbes Bldg. \#36, Tucson, AZ 85721

Richard D. Gibson

Pinal County Cooperative Extension 820 E. Cottonwood Lane, Bldg. C, Casa Grande, AZ 85222-2726

Robert E. Call

Cochise County Cooperative Extension 450 S. Haskell Avenue, Willcox, AZ 85643-2790

\section{Humberto Núñez \\ Instituto Nacional de Investigaciones Forestales, Agricolas y Pecuarias, Hermosillo Sonora, Mexico}

Additional index words. Carya illinoensis, 'Western Schley', leaf sampling, leaf analysis, balance index, foliar analysis

\begin{abstract}
Measurement of nutrients in leaf tissue is a practical method of monitoring the nutritional status of perennial crops such as pecan (Carya illinoinensis, Wang. C. Koch). Accurate interpretations require known standard concentrations for the crop and region. To determine standard concentrations for pecans, focusing on those grown in the desert southwest, we conducted a survey of 135 'Western Schley' pecan trees in Arizona for 2 years. Leaf nutrient concentrations and yield were collected for each tree. Leaf nutrient concentrations from the highest yielding trees (50th yield percentile) were used to calculate a mean and $\mathrm{CV}$ for each nutrient. Results were compared with data from New Mexico, Georgia, and Sonora, Mexico. Relatively large differences were noted in mean $\mathrm{K}, \mathrm{Ca}, \mathrm{B}, \mathrm{Cu}, \mathrm{Fe}, \mathrm{Mn}$, and $\mathrm{Zn}$ levels. Nutrient interpretation ranges were calculated based on Arizona population statistics using the balance index method.
\end{abstract}

Leaf sampling provides a practical means for evaluating plant nutrient status because leaf tissue composition reflects the amount of nutrients taken up and assimilated by the plant. Leaf tissue analysis has been widely used for nutrient evaluation of a large range of crop species, and it is particularly useful for monitoring long-term fertility management in perennial crops such as pecans (O'Barr and McBride, 1980).

The procedures for collecting, handling, and analyzing pecan leaves for nutrient concentration are well established (Herrera, 2000; O'Barr and McBride, 1980). The middle pairs of leaflets are collected from the middle leaves of the current year's growth after shoot growth has ended. Leaflets are collected from all sides of each tree. In the southwest United States, the recommended sampling period is from late July to early August. For analyses of leaf samples to be useful, nutrient concentrations must be compared against standard nutrient values. It is

\footnotetext{
Received for publication 13 Feb. 2006. Accepted for publication 3 Apr. 2006.

${ }^{1}$ To whom correspondence should be addressed;
} e-mail walworth@ag.arizona.edu critical that appropriate standards be used for interpretations to be valid.

It is recognized that crop plants grown in various regions of the country may vary in nutrient composition, although the crops grown in each region may be healthy. For example, Walworth and Sumner (1988) noted that the acceptable ear leaf $\mathrm{Mg}$ level for corn (Zea mays, L.) grown in the acidic, highly weathered soils of the southeastern United States is lower than that for corn grown in the midwestern part of the country. Thus, it is desirable to generate plant leaf tissue standards in the same geographic and climatic area in which trees are to be sampled. Comparison of nutrient analysis results with incorrect standards can lead to errors in interpretation and subsequent fertilization practices.

Establishment of nutrient standards requires a database that links crop yield parameters (yield and quality) with leaf nutrient levels. It is further necessary to have a range of both leaf nutrient levels and crop yields. Kenworthy (1961) developed a method for use in perennial orchard species in which natural and grower-induced variation used rather than that imposed by fertilizer treatments in typical experimental designs. This method precludes development of direct relationships between leaf nutrient concentration and yield or use of statistical regression. However, Kenworthy found that the mean tissue concentration from the higher yielding members of a data set generated in this fashion provided a good estimate of acceptable nutrient concentration values. Furthermore, he found that the $\mathrm{CV}$ associated with this population of data points provides a practical method of determining the normal or acceptable range of each nutrient.

We conducted a 2-year survey of production pecan orchards in Arizona to generate a database for development of leaf tissue nutrient standards. We used similar surveys conducted in New Mexico, Georgia, and Sonora, Mexico, for comparative purposes.

\section{Materials and Methods}

Plots were established in 2003 in 27 blocks of 'Western Schley' pecans in 12 orchards across southeastern Arizona, thus providing a wide range of soils and management techniques, including pruning, tree spacings, and irrigation regimes. In each block, 5 trees with heavy nut crops (identified visually) were selected to be monitored, giving a total of 135 trees. A composite leaf sample was collected from each tree following standard leaf sampling protocol (Herrera, 2000; O'Barr and McBride, 1980). Samples were immediately refrigerated for transport to the laboratory, where they were washed in a dilute phosphate-free detergent, rinsed three times in deionized water, and finally rinsed in ultrapure $(18.2 \mathrm{M} \Omega)$ water. Leaves were then dried for 24 hours at $60{ }^{\circ} \mathrm{C}$ and ground with a mortar and pestle. Samples were analyzed for $\mathrm{N}$ by combustion using a Leco FP528. Ground leaf tissue was digested using a block digester (Martin Machine, Magnum Series F-4) with $\mathrm{HNO}_{3}, \mathrm{HCl}$, and $\mathrm{H}_{2} \mathrm{O}_{2}$. All remaining nutrients $(\mathrm{Ca}, \mathrm{Mg}, \mathrm{K}, \mathrm{P}, \mathrm{S}, \mathrm{B}, \mathrm{Zn}, \mathrm{Fe}, \mathrm{Mn}$, $\mathrm{Ni}$, and $\mathrm{Cu}$ ) were measured in the digestate by ICP on a Spectro Modula M120 (Kalra and Maynard, 1998).

Yield data were collected by manually gathering nuts from wedge-shaped areas under each tree at the end of the growing season (Worley and Smith, 1984). Each wedge constituted $1 \%$ of the area under each tree. Four wedges were sampled per tree. The harvested samples were cleaned to remove shucks and debris and allowed to air dry. The sample was weighed and yields were converted to "per hectare' yields based on orchard tree spacing. This procedure was repeated using the same trees in 2004, thus giving us data from both an 'on' and 'off' year. The only change was a reduction in the number of trees to 120 , because several blocks were lost as a result of land development.

A database was constructed such that the data from each tree, in each year, represented one data point. It has been demonstrated using the high-yielding members of a database reduces skew, although the actual yield cutoff selected has a minimal impact on relevant population statistics (Letzsch and Sumner, 1984). Data were sorted based on 
yield and, using the 50th yield percentile as a cutoff, trees yielding less than $1121 \mathrm{~kg}$ per hectare were discarded from the data set. The means and CVs for each element were determined using the remaining high-yield trees.

Recommended concentration ranges were determined using the balance index method of Kenworthy (1961). This method normalizes sample nutrient concentrations based on a standard value (the mean concentration) and the $\mathrm{CV}$ by the following equations, where $\mathrm{X}=$ sample nutrient concentration, $\mathrm{CV}=$ population coefficient of variation, $S=$ population mean, and $\mathrm{B}=$ balance index.

$$
\begin{aligned}
B= & {\left[\left(\frac{X}{S}\right) \times 100\right]-\left[\left(100-\left\{\left(\frac{X}{S}\right)\right.\right.\right.} \\
& \left.\times 100\}) \times\left(\frac{C V}{100}\right)\right]
\end{aligned}
$$

if $\mathrm{X}<\mathrm{S}$ and

$$
\begin{aligned}
B= & {\left[\left(\frac{X}{S}\right) \times 100\right]-\left[\left(\left\{\left(\frac{X}{S}\right) \times 100\right\}\right.\right.} \\
& \left.-100) \times\left(\frac{C V}{100}\right)\right]
\end{aligned}
$$

if $\mathrm{X}>\mathrm{S}$.

'Low' nutrient concentration ranges are defined by balance indices falling between 50 and 82 , 'normal' nutrient concentration ranges by balance indices between 83 and 116 , and 'high' by indices from 117 to 150 (Kenworthy, 1961).

Arizona data were compared with nutrient concentrations reported for Georgia pecans by Beverly and Worley (1992), concentrations calculated from data collected in the Mesilla Valley in New Mexico (McCaslin and Boyse, 1999) and concentrations from data collected in Sonora, Mexico (Núñez, et al., 2001). The Georgia concentrations were based on the 75th yield percentile (n range $=274-641)$, whereas the New Mexico and Arizona values were based on the 50th yield percentile ( $\mathrm{AZ} \mathrm{n}=237$; NM $\mathrm{n}=22$ ). A lower yield cutoff was selected for the New Mexico and Arizona data because those data sets contain fewer members and higher overall yield levels. As noted (Letzsch and Sumner, 1984), the yield cutoff has a negligible effect on nutrient concentration means. The Sonora, Mexico, data were only collected from high-yielding trees, so the entire database population was used $(n=30)$. Means were compared by analysis of variance and separated by least significant difference $\left(\mathrm{LSD}_{0.05}\right)$.

\section{Results and Discussion}

Mean leaf nutrient concentrations determined from data collected in Arizona, along with those from Georgia, New Mexico, and Sonora, Mexico, are presented in Table 1. The mean $\mathrm{N}$ concentrations from New Mex-

\begin{tabular}{|c|c|c|c|c|c|}
\hline & & Arizona & New Mexicow & Sonora $^{\mathrm{x}}$ & Georgia $^{y}$ \\
\hline Nitrogen & & $25.5 b^{z}$ & $24.7 \mathrm{c}^{\mathrm{z}}$ & $24.8 \mathrm{c}^{\mathrm{z}}$ & $27.2 \mathrm{a}^{\mathrm{z}}$ \\
\hline Phosphorus & & $1.32 \mathrm{~b}$ & $1.30 \mathrm{~b}$ & - & $1.40 \mathrm{a}$ \\
\hline Potassium & & $12.6 \mathrm{~b}$ & $13.3 \mathrm{a}$ & $9.1 \mathrm{~d}$ & $10.2 \mathrm{c}$ \\
\hline Calcium & $\mathrm{g} \cdot \mathrm{kg}^{-1}$ & $20.2 \mathrm{a}$ & $14.7 \mathrm{c}$ & $15.9 \mathrm{~b}$ & $14.5 \mathrm{c}$ \\
\hline Magnesium & & $4.94 \mathrm{a}$ & $4.17 \mathrm{c}$ & $4.6 \mathrm{~b}$ & $3.82 \mathrm{~d}$ \\
\hline Sulfur & & $1.72 \mathrm{~b}$ & $2.23 \mathrm{a}$ & - & - \\
\hline Boron & & $111 \mathrm{~b}$ & $137 \mathrm{a}$ & - & $40 \mathrm{c}$ \\
\hline Copper & & $7.9 \mathrm{c}$ & $12.0 \mathrm{a}$ & $7.2 \mathrm{~d}$ & $9.69 \mathrm{~b}$ \\
\hline Iron & $\mathrm{mo} \cdot \mathrm{kg}^{-1}$ & $62 \mathrm{c}$ & $67 \mathrm{c}$ & $214 \mathrm{a}$ & $89 \mathrm{~b}$ \\
\hline Manganese & $\mathrm{mg} \cdot \mathrm{kg}$ & $397 \mathrm{a}$ & $85 \mathrm{c}$ & $324 \mathrm{~b}$ & $324 \mathrm{~b}$ \\
\hline Nickel & & 11.4 & - & - & - \\
\hline Zinc & & $174 \mathrm{a}$ & $73 \mathrm{c}$ & $54.6 \mathrm{~d}$ & $126 \mathrm{~b}$ \\
\hline
\end{tabular}
ico $\left(24.7 \mathrm{~g} \cdot \mathrm{kg}^{-1}\right)$ and Sonora $\left(24.8 \mathrm{~g} \cdot \mathrm{kg}^{-1}\right)$

Table 1. Means of leaf nutrient concentrations from high-yielding trees in commercial pecan orchards in Arizona, Georgia, New Mexico, and Sonora, Mexico.

${ }^{2}$ Numbers in each row followed by different letters are statistically different at the 0.05 level based on analysis of variance with separation by least significant difference $\left(\mathrm{LSD}_{0.05}\right)$.

'Beverly and Worley, 1992.

'Núñez et al., 2001.

"McCaslin and Boyse, 1999.

were nearly identical and lower $(P<0.05)$ than that from Arizona $\left(25.5 \mathrm{~g} \cdot \mathrm{kg}^{-1}\right)$, whereas those from Georgia $\left(27.2 \mathrm{~g} \cdot \mathrm{kg}^{-1}\right)$ were significantly higher than Arizona's. The values from the 3 western locations are at the bottom of or below the sufficiency ranges reported by Jones et al. (1991) $\left(27.0-35.0 \mathrm{~g} \cdot \mathrm{kg}^{-1}\right)$ or

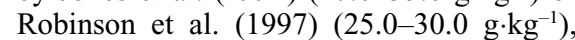
suggesting that current standards may be too high. The phosphorus mean from Georgia $\left(1.40 \mathrm{~g} \cdot \mathrm{kg}^{-1}\right)$ was significantly higher than those from Arizona or New Mexico (1.32 and $1.30 \mathrm{~g} \cdot \mathrm{kg}^{-1}$, respectively). All levels are near the bottom of or below current sufficiency ranges reported by Jones et al. (1991) and Robinson et al. (1997) (1.4-3.0, and 1.2$3.0 \mathrm{~g} \cdot \mathrm{kg}^{-1}$, respectively), suggesting that the published ranges are too high for nut-bearing pecans. However, in contrast to the values from this study and the others cited here, Sparks (1989) reported that dry weight of pecan seedlings was maximized by leaf $\mathrm{P}$ levels of 1.9 to $2.2 \mathrm{~g} \cdot \mathrm{kg}^{-1}$, although deficiency symptoms were only noted when leaf $\mathrm{P}$ fell to $0.8 \mathrm{~g} \cdot \mathrm{kg}^{-1}$. Potassium means ranged from 9.1 to $13.3 \mathrm{~g} \cdot \mathrm{kg}^{-1}$ versus sufficiency ranges of $12.5-25.0$ and 7.5-15.0 $\mathrm{g} \cdot \mathrm{kg}^{-1}$ (Jones et al., 1991 and Robinson et al., 1997, respectively).

Calcium levels were higher in leaves collected from Arizona trees $\left(20.2 \mathrm{~g} \cdot \mathrm{kg}^{-1}\right)$ compared with other locations (14.5 to 15.9 $\left.\mathrm{g} \cdot \mathrm{kg}^{-1}\right)$. The mean value from Arizona was above the sufficiency range of Jones et al. (1991) (10.0-17.5 g. $\left.\mathrm{kg}^{-1}\right)$. Magnesium levels were also highest in Arizona samples and lowest in those from Georgia. The differences in $\mathrm{Ca}$ and $\mathrm{Mg}$ levels may be reflective of the relatively high base saturation generally found in arid region soils versus the acidic, highly leached soils of Georgia. As noted previously, ear leaf $\mathrm{Mg}$ levels were lower in corn grown in Georgia than in the younger, less weathered soils of the midwest. All of the Mg levels were considerably higher than leaf $\mathrm{Mg}$ levels causing $\mathrm{Mg}$ deficiency (2.0 $\left.\mathrm{g} \cdot \mathrm{kg}^{-1}\right)$ (Sparks, 1976a) and are within recommended sufficiency ranges of 3.0 to $6.0 \mathrm{~g} \cdot \mathrm{kg}^{-1}$ (Jones et al., 1991) and 3.0 to $7.0 \mathrm{~g} \cdot \mathrm{kg}^{-1}$ (Robinson et al., 1997).
Boron levels were higher in Arizona and New Mexico than in Georgia. Arizona and New Mexico values (111 and $137 \mathrm{mg} \cdot \mathrm{kg}^{-1}$, respectively) are higher than the sufficiency ranges of Jones et al. (1991) (15-50 mg. $\left.\mathrm{kg}^{-1}\right)$ or Robinson et al. (1997) $\left(20-50 \mathrm{mg} \cdot \mathrm{kg}^{-1}\right)$. Blackmon and Winsor (1946) reported B toxicity associated with a leaf concentration of $530 \mathrm{mg} \cdot \mathrm{kg}^{-1}$ and recommended 312 to 375 $\mathrm{mg} \cdot \mathrm{kg}^{-1}$ as a safe level.

Copper concentrations in New Mexico samples were higher than in those from other locations. All were within the sufficiency ranges of Jones et al. (1991) (6-30 $\left.\mathrm{mg} \cdot \mathrm{kg}^{-1}\right)$ and Robinson et al. (1997) (5-50 $\left.\mathrm{mg} \cdot \mathrm{kg}^{-1}\right)$.

Mean Fe levels were much higher in Sonora Mexico leaves $\left(214 \mathrm{mg} \cdot \mathrm{kg}^{-1}\right)$ than in leaves from other locations. The leaves from Sonora were washed before analysis, so we do not believe that soil contamination is the source of the leaf Fe but offer no explanation for the observed levels. Leaf Fe concentrations in samples collected in Sonora during the 2005 growing season were found to be similar to those reported here (data not shown). Georgia Fe levels $\left(89 \mathrm{mg} \cdot \mathrm{kg}^{-1}\right)$ are higher than those from Arizona $\left(62 \mathrm{mg} \cdot \mathrm{kg}^{-1}\right)$ or New Mexico $\left(67 \mathrm{mg} \cdot \mathrm{kg}^{-1}\right)$, differences that may be related to the relatively weathered, acidic soils found in Georgia. Sparks (1976b) noted $\mathrm{Fe}$ deficiency symptoms when leaf $\mathrm{Fe}$ concentrations were $50 \mathrm{mg} \cdot \mathrm{kg}^{-1}$, whereas trees with $64 \mathrm{mg} \cdot \mathrm{kg}^{-1}$ had no symptoms. Iron is considered sufficient if it is between 50 and $300 \mathrm{mg} \cdot \mathrm{kg}^{-1}$ (Jones et al., 1991; Robinson et al., 1997).

Manganese levels in pecan leaves collected in Arizona $\left(397 \mathrm{mg} \cdot \mathrm{kg}^{-1}\right.$ ) were higher $(P<0.05)$ than those from Georgia (324 mg. $\mathrm{kg}^{-1}$ ) and Sonora (324 mg $\left.\cdot \mathrm{kg}^{-1}\right)$, and considerably higher than those from New Mexico $\left(85 \mathrm{mg} \cdot \mathrm{kg}^{-1}\right)$. High Mn levels were expected in pecans grown in acidic, southeastern soils, but not in those grown in alkaline Arizona and Sonora soils. The reason for high levels of Mn in Arizona and Sonora trees is not known; however, Mn toxicity was visually identified, and leaf concentrations exceeding $5000 \mathrm{mg} \cdot \mathrm{kg}^{-1}$ were observed during the Arizona survey (data not shown). 
Manganese levels in New Mexico pecans may be lower because the surveyed area is comprised of relatively sandy river valley soils, whereas Arizona and Sonora pecan production is largely on upland soils. Deficiency symptoms have been related to a leaf Mn level of $7 \mathrm{mg} \cdot \mathrm{kg}^{-1}$ (Smith and Cheary, 2001) and toxicity with a level of $577 \mathrm{mg} \cdot \mathrm{kg}^{-1}$ (Storey et al., 1985); however, trees in the Arizona survey with levels of 800 to $1000 \mathrm{mg} \cdot \mathrm{kg}^{-1}$ did not exhibit toxicity symptoms. Sufficiency ranges have been reported to be 200 to $500 \mathrm{mg} \cdot \mathrm{kg}^{-1}$ (Jones et al., 1991) and 150 to $500 \mathrm{mg} \cdot \mathrm{kg}^{-1}$ (Robinson et al., 1997).

All of the trees in the Arizona survey were foliarly fertilized with Zn. Not surprisingly, the mean $\mathrm{Zn}$ level was $174 \mathrm{mg} \cdot \mathrm{kg}^{-1}$, which is well above the sufficiency range of 50 to $100 \mathrm{mg} \cdot \mathrm{kg}^{-1}$ (Jones et al., 1991; Robinson et al., 1997). Zinc levels from the other locations were lower $(P<0.05)$ than those found in Arizona, but still within the sufficiency range.

'Low', 'normal', and 'high' nutrient ranges were constructed based on the ranges of the balance index method (Kenworthy, 1961) from the Arizona data (Table 2). In general, all the nutrient ranges are in agreement with published ranges. However, the lower limit of the Arizona N range (20.5 g. $\left.\mathrm{kg}^{-1}\right)$ is considerably lower than that of Jones et al. (1991) (27.0 $\mathrm{g} \cdot \mathrm{kg}^{-1}$ ) or Robinson et al., (1997) (25.0 $\left.\mathrm{g} \cdot \mathrm{kg}^{-1}\right)$, suggesting that the published ranges may be too high. Similarly, the lower end of the Arizona normal $\mathrm{P}$ range is below the published ranges. In contrast, the Arizona $\mathrm{Ca}$ range (15.7-24.2 $\left.\mathrm{g} \cdot \mathrm{kg}^{-1}\right)$ is higher than the published ranges (10.0-17.5 and 7.0-15.0, Jones et al., 1991 and Robinson et al., 1997, respectively), as is the lower limit of our $\mathrm{Mg}$ range.

The Arizona B range $\left(74-146 \mathrm{mg} \cdot \mathrm{kg}^{-1}\right)$ is considerably higher than the published ranges of Jones et al. (1991) and Robinson et al. (1997) but close to the New Mexico range of 50 to $200 \mathrm{mg} \cdot \mathrm{kg}^{-1}$ of Herrera (1998). The bottom of 'normal' Fe range for Arizona $\left(43-81 \mathrm{mg} \cdot \mathrm{kg}^{-1}\right)$ is lower than the concentration reported to coincide with Fe deficiency symptoms by Sparks (1976b) but similar to the ranges of Herrera (1998) (50-250 $\mathrm{mg} \cdot \mathrm{kg}^{-1}$ ) and of Jones et al. (1991) and Robinson et al. (1997) (50-300 $\left.\mathrm{mg} \cdot \mathrm{kg}^{-1}\right)$. No visual $\mathrm{Fe}$ deficiency symptoms were observed in any of the Arizona trees monitored.

The 'normal' range of Mn levels in Arizona is 104 to $674 \mathrm{mg} \cdot \mathrm{kg}^{-1}$. This range is much broader than those of Jones et al. (1991) and Robinson et al. (1997) but close to the New Mexico range of 100 to $600 \mathrm{mg} \cdot \mathrm{kg}^{-1}$ of Herrera (1998). In addition, observations suggest that Mn concentration can exceed the Arizona range without noticeable deleterious effects and that $\mathrm{Mn}$ toxicity does not occur until leaf Mn concentrations are above $1200 \mathrm{mg} \cdot \mathrm{kg}^{-1}$ (data not shown).

Mouse-ear in pecan trees in Georgia has recently been related to nickel deficiency in trees with leaf $\mathrm{Ni}$ concentrations below

Table 2. 'Low,' 'normal,' and 'high' pecan leaf tissue nutrient concentration ranges based on population means and coefficients of variation of Arizona pecan trees in the 50th yield percentile of sampled trees and previously published nutrient sufficiency ranges.

\begin{tabular}{|c|c|c|c|c|c|c|}
\hline \multirow[b]{2}{*}{ Nutrient } & & \multirow[b]{2}{*}{ Low } & \multirow[b]{2}{*}{ Normal } & \multirow[b]{2}{*}{ High } & \multicolumn{2}{|c|}{ Sufficiency range } \\
\hline & & & & & Jones et al., 1991 & Robinson et al., 1997 \\
\hline Nitrogen & & $11.5-20.4$ & $20.5-29.5$ & $29.6-38.5$ & $27.0-35.0$ & $25.0-30.0$ \\
\hline Phosphorus & & $0.3-0.9$ & $1.0-1.5$ & $1.6-2.3$ & $1.4-3.0$ & $1.2-3.0$ \\
\hline Potassium & o. $k \sigma^{-1}$ & $4.5-9.9$ & $10.0-15.8$ & $15.9-21.5$ & $12.5-25.0$ & $7.5-15.0$ \\
\hline Calcium & $\mathrm{g} \cdot \mathrm{kg}$ & $7.2-15.8$ & $15.7-24.2$ & $24.3-32.6$ & $10.0-17.5$ & $7.0-15.0$ \\
\hline Magnesium & & $1.8-3.8$ & $3.9-5.8$ & $5.9-8.0$ & $3.0-6.0$ & $3.0-7.0$ \\
\hline Sulfur & & $0.7-1.3$ & $1.4-1.9$ & $2.0-2.7$ & - & $1.5-2.5$ \\
\hline Boron & & $4-73$ & $74-146$ & $147-217$ & $15-30$ & $25-30$ \\
\hline Copper & & $3-5$ & $6-9$ & $10-13$ & $6-30$ & $5-50$ \\
\hline Iron & & $6-42$ & $43-80$ & $81-118$ & $50-300$ & $50-300$ \\
\hline Manganese & $\mathrm{mg} \cdot \mathrm{kg}^{-1}$ & $0-103$ & $104-673$ & $674-1227$ & $200-500$ & $150-300$ \\
\hline Nickel & & $2.8-8.4$ & $8.5-14.2$ & $14.3-20.0$ & - & - \\
\hline Zinc & & $0-85$ & $86-256$ & $257-423$ & $50-100$ & $50-100$ \\
\hline
\end{tabular}

$4.0 \mathrm{mg} \cdot \mathrm{kg}^{-1}$ (Wood et al., 2004). This concentration falls into the middle of the 'low' range of concentrations for Arizona trees. Therefore, staying within the normal range should help to prevent this disease.

The leaf $\mathrm{Zn}$ concentration range from the Arizona study is probably not reflective of tree $\mathrm{Zn}$ requirements because foliar $\mathrm{Zn}$ applications were made to all trees in the survey. Although the collected leaves were thoroughly washed to remove spray residues, the 'normal' $\mathrm{Zn}$ concentration range of 86 to $257 \mathrm{mg} \cdot \mathrm{kg}^{-1}$ was higher than other published ranges or the $48 \mathrm{mg} \cdot \mathrm{kg}^{-1}$ critical concentration reported by Sparks (1994). Thus, the Arizona data may be skewed by an abundance of trees with excessive $\mathrm{Zn}$ concentrations resulting from foliar $\mathrm{Zn}$ applications.

Leaf nutrient concentration ranges developed through this study are suggested for regional interpretation of pecan leaf samples. The variations noted in mean nutrient concentrations from Arizona, Georgia, New Mexico, and Sonora, Mexico, suggest that regional nutrient sufficiency ranges should be considered to ensure accurate nutritional diagnoses.

\section{Literature Cited}

Beverly, R.B. and R.E. Worley. 1992. Preliminary DRIS diagnostic norms for pecan. HortScience 27:271.

Blackmon, G.H. and H.W. Winsor. 1946. Boron uptake in pecans. Amer. Soc. Hort. Sci. 47:149-152.

Herrera, E. 2000. Sampling pecan leaves for analysis. College of Agriculture and Home Economics Guide H-619. New Mexico State University, Las Cruces, NM.

Herrera, E. 1998. Interpreting leaf analysis and deficiency symptoms of pecans. College of Agriculture and Home Economics Guide H-617. New Mexico State University, Las Cruces, NM.

Jones, J.B., Jr., B. Wolf, and H.A. Mills. 1991. Plant Analysis Handbook. Micro-Macro Publishing, Inc., Athens, GA.

Kalra, Y.P. and D.G. Maynard. 1998. Microwave digestion of plant tissue in an open vessel. Pp. 63-67. In: Y. Kalra (ed.), Handbook of Reference Methods for Plant Analysis. CRC Press, New York.
Kenworthy, A.L. 1961. Interpreting the balance of nutrient-elements in leaves of fruit trees. Pp. 28-43. In: W. Reuther (ed.), Plant Analysis and Fertilizer Problems. Amer. Inst. Biol. Sci., Pub. No. 8, Washington, D.C.

Letzsch, W.S. and M.E. Sumner. 1984. Effect of population size and yield level in selection of diagnosis and recommendation integrated system (DRIS) norms. Commun. Soil Sci. Plant Anal. 15:997-1006.

McCaslin, R.D. and L.G. Boyse. 1999. Nutrient status of pecans in the Mesilla Valley. Western Pecan Conference Proceedings, 3389-94: Las Cruces, New Mexico, Mar. 7-9, 1999.

Núñez, J.H.M. 2001. Nutricion y fertilizacion. Pp. 63-91. In: Núñez, J.H.M., B.G. Valdez, G.D. Gerardo, and E.C. Valenzuela. El nogal pecanero en Sonora. Libro Tecnico No. 3. Instituto Nacional de Investigaciones Forestales. Agricolas Y Pecuarias. Hermisillo, Sonora, Mexico.

O'Barr, R.D. and J.M. McBride. 1980. Pecan leaf sampling for commercial groves. Pecan South 7:42-44.

Robinson, J.B., M. Treeby, and R.A. Stephenson. 1997. Fruits, vines and nuts. Pp. 347-382. In: D.J. Reuter and J.B. Robinson (eds.). Plant Analysis, An Interpretation Manual. CSIRO Publishing, Collingwood, Victoria, Australia.

Smith, M.W. and B.S. Cheary. 2001. Manganese deficiency in pecan. HortScience 36:10751076.

Sparks, D. 1976a. Magnesium nutrition \& the pecan - a review. Pecan South 13:384-387.

Sparks, D. 1976b. Iron deficiency in pecans. Pecan South 13:448-449.

Sparks, D. 1989. Current recommendations for leaf P levels too low, study shows. Pecan South 23:9-13.

Sparks, D. 1994. Leaf zinc for maximum yield, growth in pecan. Pecan South 27:19-24.

Storey, J.B., D. Joy, and L. Sistrunk. 1985. Manganese toxicity shows up as brown specks on pecan leaves. Pecan South 19:32-33.

Walworth, J.L. and M.E. Sumner. 1988. Foliar diagnosis: a review. Pp. 193-241. In: B. Tinker and A. Läuchli (eds.). Advances in Plant Nutrition, vol. 3 Praeger, New York.

Wood, B.W., C.C. Reilly, and A.P. Nyczepir. 2004. Mouse-ear of pecan: a nickel deficiency. HortScience 39:1238-1242.

Worley, R.E. and M. Smith. 1984. A method of estimating pecan yield. J. Am. Soc. Hort. Sci. 19:664. 